\title{
Analisis Kemampuan Pemecahan Masalah Matematika ditinjau dari Tipe Kepribadian Siswa Madrasah Tsanawiyah
}

\section{Mariya Sulastri ${ }^{*}$, Laila Hayati ${ }^{2}$, Nurul Hikmah², Syahrul Azmi ${ }^{2}$}

\author{
${ }^{1}$ Mahasiswa Pendidikan Matematika, FKIP, Universitas Mataram, Mataram \\ ${ }^{2}$ Dosen Pendidikan Matematika, FKIP, Universitas Mataram, Mataram
}

mariyasulastri@gmail.com

Diterima: 17-12-2021; Direvisi: 30-12-2021; Dipublikasi: 30-12-2021

\begin{abstract}
This study aims to describe the mathematical problem solving abilities in terms of students personality types of grade VIII at MTs Al-Ma'arif NU Qamarul Huda Narmada academic year 2020/2021. This type of research is a qualitative descriptive with a quantitative approach. The sampling technique used saturated sampling and each 2 students were selected to represent each personality types. The data collection technique used are personality type questionnaires, mathematical problem solving ability tests, and interviews. The data analysis techniques used quantitative data analysis and qualitative data analysis that are data reduction, data presentation and conclusions. The result of this study are students with introvert and extrovert personality types are not able to write down the stage of understanding the problem, do the stage of making a plan by writing them into mathematical form, able to write down the problem solving systemtatically but there are some errors, write the conclusion of the answer though it's not quite right. While students with ambivert personality types are able to do the stage of understanding the problem by writing down even though it's incomplete, write a plan for solving the problem by directly writing it into mathematical form, are able to write the solution of the problem according to the plan even though there are some missteps, re-examine and write down the conclusion even though there are error in the results.
\end{abstract}

Keywords: the mathematical problem-solving abilities; introvert; extrovert; ambivert

\begin{abstract}
Abstrak
Penelitian ini bertujuan untuk mendeskripsikan kemampuan pemecahan masalah matematika ditinjau dari tipe kepribadian siswa kelas VIII MTs Al-Ma'arif NU Qamarul Huda Narmada Tahun Pelajaran 2020/2021. Jenis penelitian ini adalah deskriptif kualitatif dengan pendekatan kuantitatif. Teknik pengambilan sampel menggunakan sampling jenuh dan dipilih masingmasing 2 siswa mewakili setiap tipe kepribadian. Teknik pengumpulan data menggunakan angket tipe kepribadian, tes kemampuan pemecahan masalah dan wawancara. Teknik analisis data menggunakan analisis data kuantitatif dan analisis data kualitatif yaitu reduksi data, penyajian data, dan menarik kesimpulan. Hasil penelitian ini adalah siswa tipe kerpibadian introvert dan extrovert belum mampu melakukan tahap memahami masalah, melakukan tahap membuat rencana dengan langsung menuliskannya ke bentuk matematika, menuliskan penyelesaian masalah dengan sistematis tetapi masih ada beberapa kesalahan, menuliskan kesimpulan jawaban meskipun kurang tepat. Sedangkan siswa tipe kepribadian ambivert mampu melakukan tahap memahami masalah meskipun kurang lengkap, menuliskan rencana penyelesaian dari soal dengan langsung menuliskannya ke bentuk matematika, menuliskan penyelesaian soal sesuai rencana meskipun terdapat beberapa kesalahan langkah, melakukan pemeriksaan kembali dan menuliskan kesimpulan meskipun terdapat kesalahan hasil.
\end{abstract}

Kata Kunci: kemampuan pemecahan masalah matematika; introvert; extrovert; ambivert 


\section{PENDAHULUAN}

Pendidikan memiliki berbagai cabang ilmu pengetahuan dan salah satunya yang paling penting untuk dipelajari adalah matematika. Karena matematika merupakan salah satu ilmu pengetahuan yang penting dalam kehidupan sehari-hari yang mendasari ilmu-ilmu pengetahuan lainnya (Aryanto, Suharto, Setiawan, Hobri, \& Oktavianingtiyas, 2018). Matematika merupakan ilmu universal yang mendasari perkembangan teknologi modern, serta mempunyai peran penting dalam mengembangkan daya pikir manusia (Turmuzi \& Hayati, 2012). Salah satu aspek penting dalam kurikulum matematika adalah pemecahan masalah. Pentingnya kemampuan pemecahan masalah matematika tercermin dari pendapat Branca (dalam Rahmawati, 2018) yaitu merupakan salah satu tujun penting dalam pembelajaran matematika bahkan proses pemecahan masalah merupakan jantungnya matematika, sehingga untuk meningkatkan kemampuan pemecahan masalah, diperlukan keterampilan dalam menyusun langkah-langkah penyelesaian masalah. Langkah-langkah atau tahap penting yang harus ditempuh oleh siswa dalam pemecahan masalah menurut Polya (dalam Hidayat \& Sariningsih, 2018). diantaranya adalah (1) memahami masalah, (2) menyusun rencana, (3) melaksanakan rencana, dan (4) melihat kembali. Satu tahap ke tahap berikutnya dalam memecahkan masalah tersebut saling mendukung untuk menghasilkan pemecahan masalah dari soal terkait. Siswa berperan dalam memahami setiap langkah pemecahan masalah agar proses berpikir siswa berjalan dengan baik.

Tahapan atau langkah pemecahan masalah tersebut tidak seluruhnya dikuasai oleh siswa. Seperti yang terjadi pada siswa kelas VIII MTs Al-Ma'arif NU Qamarul Huda Narmada. Berdasarkan hasil wawancara dengan guru matematika di sekolah tersebut pada bulan Desember 2020, dapat diketahui bahwa masih terdapat siswa yang belum mampu melakukan tahapan pemecahan masalah matematika dengan lengkap. Diantaranya terdapat siswa yang tidak memahami maksud soal sehingga tidak menuliskan informasi-informasi yang ada pada soal, serta mengalami kesulitan dalam mengembangkan solusi permasalahan dari soal yang menyebabkan kesalahan hasil akhir pada jawaban.

Ketidakmampuan siswa dalam melakukan semua tahapan pemecahan masalah matematika ini dapat disebabkan oleh beberapa faktor salah satunya adalah karakteristik siswa. Salah satu karakteristik tersebut adalah tipe kepribadian. Hal ini sesuai dengan pendapat dari Pimta, Tayruakham, \& Nuangchalerm (2009) yang menyatakan bahwa kemampuan pemecahan masalah matematika disebabkan oleh faktor langsung dan tidak langsung, faktor tidak langsung yaitu kemampuan diri yang berasal dari dalam diri siswa sehingga dapat dipengaruhi oleh kepribadian yang dimilikinya.

Ada banyak tipe kerpibadian yang diungkapkan oleh para ahli, salah satunya adalah tipe kepribadian dari Jung (dalam Sunaryo, 2004) yang membagi tipe kepribadian menjadi tiga bagian yaitu tipe extrovert, tipe introvert, dan tipe ambivert. Seorang introvert umumnya berkarakter tertutup, suka berfantasi, overthinking sehingga pada saat 
mengalami masalah, ia akan tenggelam dalam pikirannya sendiri dan merasa mampu menghadapi seorang diri. Sedangkan tipe extrovert merupakan seorang yang ramah, riang, mudah berhubungan dengan orang lain, spontan dalam mengungkapkan emosinya, tidak terlalu memikirkan kegagalan yang dihadapi, serta tidak banyak menganalisis dan mengkritik diri sendiri.Untuk tipe ambivert merupakan tipe yang condong kepada kedua tipe sebelumnya.

Sebagaimana perbedaan tipe kepribadian yang dimiliki setiap siswa, begitupun dengan perbedaan dalam mengikuti pembelajaran di sekolah, terutama dalam memahami setiap permasalahan matematika yang diberikan. Dari \& Budiarto (2016) berpendapat bahwa setiap siswa akan menyelesaikan soal dengan berbagai cara dan strategi yang berbedabeda, karena setiap siswa tentu memiliki pemikiran dan sudut pandang yang berbeda dalam memahami soal atau permasalahan. Widayanti (2016) juga menyampaikan perbedaan sifat dan prilaku setiap orang mempengaruhi hasil mereka ketika memecahkan masalah, karena satu orang dengan orang lainnya memiliki perbedaan dalam menerima informasi, memproses informasi, serta cara menindaklanjuti informasi tersebut.

Oleh karena itu, dilakukan suatu analisis mengenai kemampuan pemecahan masalah matematika berdasarkan tipe kepribadian yang dimiliki setiap siswa kelas VIII pada sekolah MTs Al-Ma'arif NU Qamarul Huda Narmada. Hal ini dilakukan guna mengetahui kemampuan pemecahan masalah matematika setiap tipe kepribadian. Menurut Soedjadi (dalam Susanto, 2019) melalui kegiatan pemecahan masalah diharapkan pemahaman materi matematika lebih mantap dan lebih menumbuhkan kreativitas.

\section{METODE PENELITIAN}

Jenis penelitian ini adalah deskriptif kualitatif dengan pendekatan kuantitatif. Penelitian ini menggabungkan penelitian kuantitatif dan kualitatif, dimana penelitian kuantitatif sebagai fasilitator penelitian kualitatif. Penelitian ini dilaksanakan pada semester genap tahun pelajaran 2020/2021 yang bertempat di MTs Al-Ma'arif NU Qamarul Huda Pembuwun yang berlokasi di Desa Buwun Sejati Kec. Narmada, Lomobok Barat. Tehnik pengambilan sampel menggunakan sampling jenuh karena semua populasi yaitu seluruh siswa kelas VIII berjumlah 30 siswa menjadi sampel penelitian. Untuk memperdalam hasil penelitian dipilih 2 siswa dari setiap tipe kepribadian. Instrumen yang digunakan yaitu angket tipe kepribadian, tes pemecahan masalah materi SPLDV, dan pedoman wawancara. Uji validitas yang digunakan adalah validitas isi dan validitas empiris. Validitas isi dengan bantuan 2 orang ahli sebagai validator dalam hal ini satu dosen pendidikan matematika FKIP Unram dan satu guru matematika pada sekolah tempat penelitian. Sedangkan validitas empiris dengan mengujikan instrumen kepada siswa selain subjek, kemudian di analisis menggunakan rumus korelasi product moment pearson yaitu sebagai berikut. 


$$
r_{x y}=\frac{N \cdot \sum X Y-\left(\sum X\right)\left(\sum Y\right)}{\sqrt{\left\{N \cdot\left(\sum X^{2}\right)-\left(\sum X\right)^{2}\right\}\left\{N \cdot\left(\sum Y^{2}\right)-\left(\sum Y\right)^{2}\right\}}}
$$

(Turmuzi, 2019)

Keterangan:

$r_{x y}=$ Koefisien Korelasi

$\sum X=$ Jumlah skor tiap item dari seluruh responden

$\sum Y=$ Jumlah skor tiap item dari keseluruan responden

$\mathrm{N}=$ Jumlah responden

Pedoman penskoran angket diberikan berdasarkan pilihan jawaban yang paling banyak dipilih. Jika pernyataan (a) lebih banyak dipilih maka siswa tersebut termasuk kepribadian extrovert, jika pernyataan (b) lebih banyak dipilih maka siswa tersebut termasuk tipe kepribadian introvert, dan jika pernyataan (a) dan (b) memiliki jumlah yang sama maka siswa tersebut termasuk dalam tipe kepribadian ambivert. Data hasil penelitian kemudian di analisis menggunkan analisis data menurut Miles \& Huberman (dalam Subadi, 2006) yaitu reduksi data, penyajian data, dan menarik kesimpulan. Untuk mengetahui kemampuan pemecahan masalah matematika siswa tipe kepribadian introvert, extrovert, dan ambivert, data yang diperoleh disesuaikan dengan indikator kemampuan pemecahan masalah menurut Polya.

Table 1. Indikator Pemecahan Masalah Matematika Polya

\begin{tabular}{|c|c|c|}
\hline No. & Tahap & Indikator \\
\hline 1. & $\begin{array}{l}\text { Memahami masalah } \\
\text { (understanding the problen) }\end{array}$ & $\begin{array}{l}\text { a. Mengetahui apa saja yang diketahui dan } \\
\text { ditanyakan pada masalah } \\
\text { b. Menjelaskan masalah sesuai dengan kalimat } \\
\text { sendiri }\end{array}$ \\
\hline 2. & $\begin{array}{l}\text { Membuat rencana (devising a } \\
\text { plan) }\end{array}$ & $\begin{array}{l}\text { a. Menyederhanakan masalah } \\
\text { b. Mampu membuat eksperimen dan simulasi } \\
\text { c. Mampu mencari sub-tujuan } \\
\text { d. Mengurutkan informasi }\end{array}$ \\
\hline 3. & $\begin{array}{l}\text { Melaksanakan rencana } \\
\text { (carring out the plan) }\end{array}$ & $\begin{array}{l}\text { a. Mengartikan masalah yang diberikan dalam } \\
\text { bentuk kalimat matematika } \\
\text { b. Melaksanakan strategi } \\
\text { penghitungan berlangsung }\end{array}$ \\
\hline 4. & $\begin{array}{l}\text { Melihat kembali (looking } \\
\text { back) }\end{array}$ & $\begin{array}{l}\text { a. Mengecek semua informasi dan perhitungan } \\
\text { yang terlibat } \\
\text { b. Mempertimbangkan apakah solusi logis } \\
\text { c. Melihat alternatif penyelesaian yang lain } \\
\text { d. Membaca kembali pertanyaan } \\
\text { e. Bertanya kepada diri sendiri apakah semua } \\
\text { pertanyaan sudah terjawab. }\end{array}$ \\
\hline
\end{tabular}

Selanjutnya dicari rata-rata kemampuan pemecahan masalah siswa untuk kemudian ditentukan kategorinya dengan merujuk pada indikator yang telah ditetapkan. 
Tabel 2. Interpretasi Skor Kemampuan Pemecahan Masalah Matematika

\begin{tabular}{cc}
\hline Nilai & Kategori \\
\hline $80,00-100$ & Sangat Baik \\
$65,00-79,99$ & Baik \\
$55,00-64,99$ & Cukup \\
$40,00-54,99$ & Kurang \\
$0-39,99$ & Sangat Kurang \\
\hline & Sumber: Hadi \& Radiyatul (2014)
\end{tabular}

Selanjutnya rata-rata nilai tes yang telah didapat, diklasifikasikan menjadi lima kategori berdasarkan Tabel 2 di atas.

\section{HASIL DAN PEMBAHASAN}

Pelaksanaan penelitian ini diawali dengan agenda pemberian angket tipe kepribadian yang di ikuti oleh 30 siswa kelas VIII MTs Al-Ma'arif NU Qamarul Huda Narmada tahun pelajaran 2020/2021. Setelah hasil angket dianalisis, didapatkan bahwa 21 siswa dengan tipe kepribadian introvert, 5 siswa dengan tipe kepribadian extrovert, dan 4 siswa dengan tipe kepribadian ambivert. Selanjutnya diberikan tes materi SPLDV guna mengukur kemampuan pemecahan masalah matematika setiap tipe kepribadian. Berdasarkan hasil angket, tes, dan rekomendasi dari guru mata pelajaran maka dipilih 2 siswa mewakili masing-masing tipe kepribadian untuk dilakukann wawancara mendalam.

Berdasarkan hasil analisis angket tipe kepribadian, tes, dan wawancara maka diperoleh nilai kemampuan pemecahan masalah setiap tipe kepribadian seperti pada tabel berikut.

Tabel 3. Rata-rata Hasil Tes Kemampuan Pemecahan Masalah Matematika Siswa Ditinjau dari Tipe Kepribadian

\begin{tabular}{|c|c|c|c|c|c|c|c|}
\hline \multirow[b]{2}{*}{ No } & \multirow[b]{2}{*}{$\begin{array}{c}\text { Tipe } \\
\text { kepribadian }\end{array}$} & \multicolumn{4}{|c|}{ Tahap } & \multirow{2}{*}{$\begin{array}{c}\text { Total } \\
\text { Rata- } \\
\text { rata }\end{array}$} & \multirow[b]{2}{*}{ Kategori } \\
\hline & & $\begin{array}{c}\text { Memahami } \\
\text { Masalah }\end{array}$ & $\begin{array}{l}\text { Membuat } \\
\text { Rencana }\end{array}$ & $\begin{array}{c}\text { Melaksanakan } \\
\text { Rencana }\end{array}$ & $\begin{array}{l}\text { Melihat } \\
\text { Kembali }\end{array}$ & & \\
\hline 1 & Introvert & 5,95 & 26,19 & 23,21 & 25,00 & 20,09 & $\begin{array}{l}\text { Sangat } \\
\text { Kurang }\end{array}$ \\
\hline 2 & Extrovert & 7,50 & 12,50 & 22,50 & 22,50 & 16,25 & $\begin{array}{l}\text { Sangat } \\
\text { Kurang }\end{array}$ \\
\hline 3 & Ambivert & 15,62 & 25,00 & 25,00 & 25,00 & 22,65 & $\begin{array}{l}\text { Sangat } \\
\text { Kurang }\end{array}$ \\
\hline & Total & 9,69 & 21,23 & 23,57 & 24,16 & 19,66 & $\begin{array}{l}\text { Sangat } \\
\text { Kurang }\end{array}$ \\
\hline
\end{tabular}

Berdasarkan Tabel 3 diatas dapat dilihat bahwa total rata-rata kemampuan pemecahan masalah matematika siswa ditinjau dari tipe kepribadian sangat kurang. Selanjutnya berikut dideskripsikan lebih rinci mengenai kemampuan pemecahan masalah matematika dari masing-masing tipe kepribadian.

\subsection{Tipe Kepribadian Introvert}

Berdasarkan Tabel 3 diatas, terlihat bahwa total rata-rata skor kemampuan pemecahan masalah matematika siswa tipe kepribadian introvert adalah sebesar 20,09. Hal ini menunjukkan bahwa kemampuan pemecahan masalah matematika yang dimiliki oleh 
siswa tipe kepribadian introvert masih sangat kurang. Berikut ini hasil tes kemampuan pemecahan masalah matematika subjek $\mathrm{SI}_{1}$ dan $\mathrm{SI}_{2}$.

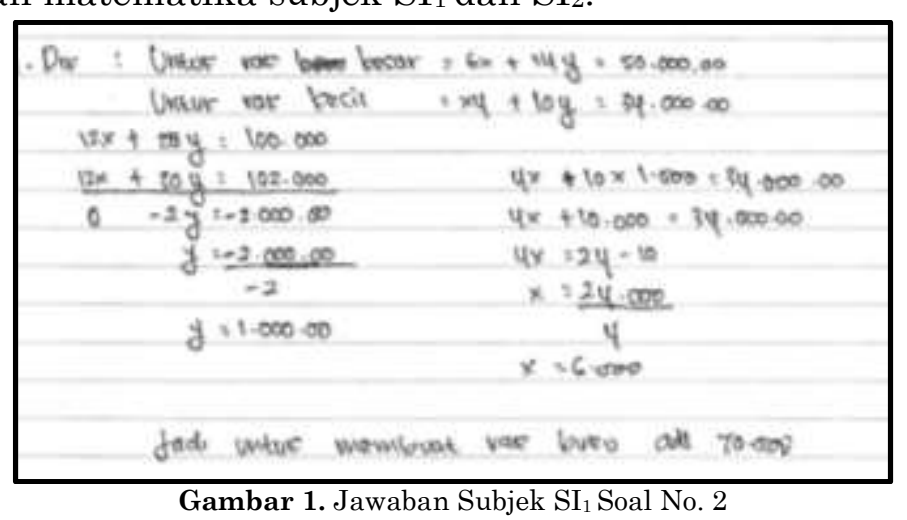

Berdasarkan Gambar 1 diatas, disimpulkan bahwa subjek $\mathrm{SI}_{1}$ mampu melakukan 3 tahapan dari 4 tahap kemampuan pemecahan masalah matematika yaitu tahap membuat rencana, melaksanakan rencana, dan melihat kembali. Sedangkan untuk tahap memahami masalah subjek $\mathrm{SI}_{1}$ belum mampu melakukannya karena tidak menuliskan informasi yang dibutuhkan pada tahap tersebut.

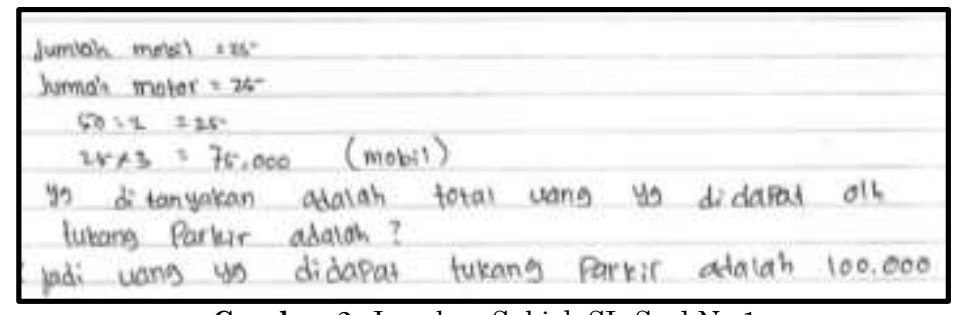

Gambar 2. Jawaban Subjek $\mathrm{SI}_{2}$ Soal No.1

Berdasarkan Gambar 2 diatas, dapat dilihat bahwa subjek $\mathrm{SI}_{2}$ pada soal no. 1 masih salah dalam menuliskan yang diketahui dan ditanyakan dan tidak menuliskan perencanaan, menuliskan langkah-langkah penyelesaian meskipun masih terdapat kesalahan. Dan untuk tahap melihat kembali subjek $\mathrm{SI}_{2}$ sudah dapat melakukannya dengan menuliskan kesimpulan jawaban.

\subsection{Tipe Kepribadian Extrovert}

Berdasarkan Tabel 3 diatas, terlihat bahwa total rata-rata skor kemampuan pemecahan masalah matematika siswa tipe kepribadian extrovert adalah sebesar 16,25. Hal ini menunjukkan bahwa kemampuan pemecahan masalah matematika yang dimiliki oleh siswa tipe kepribadian extrovert masih sangat kurang. Kemudian untuk mengetahui secara lebih jelas kemampuan pemecahan masalah matematika siswa tipe kepribadian extrovert, berikut ditampilkan hasil tes subjek $\mathrm{SE}_{1}$ dan subjek $\mathrm{SE}_{2}$. 


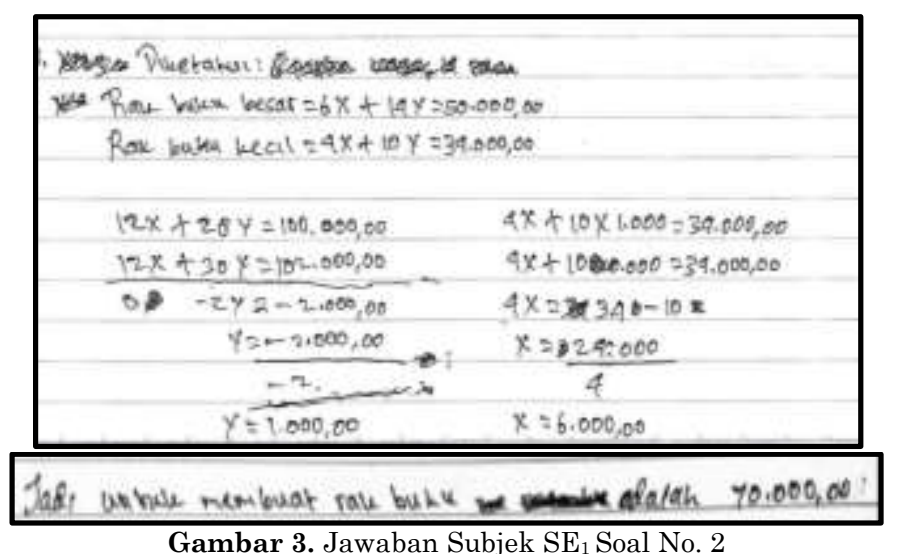

Berdasarkan Gambar 3 diatas, dapat dilihat bahwa subjek $\mathrm{SE}_{1}$ mampu melakukan 3 dari 4 tahapan kemampuan pemecahan masalah matematika, yaitu tahap membuat rencana, melaksanakan rencana, dan tahap melihat kembali. Sedangkan untuk tahap memahami masalah, subjek $\mathrm{SE}_{1}$ belum mampu menuliskan informasi yang dibutuhkan tetapi dapat menyebutkannya ketika wawancara.

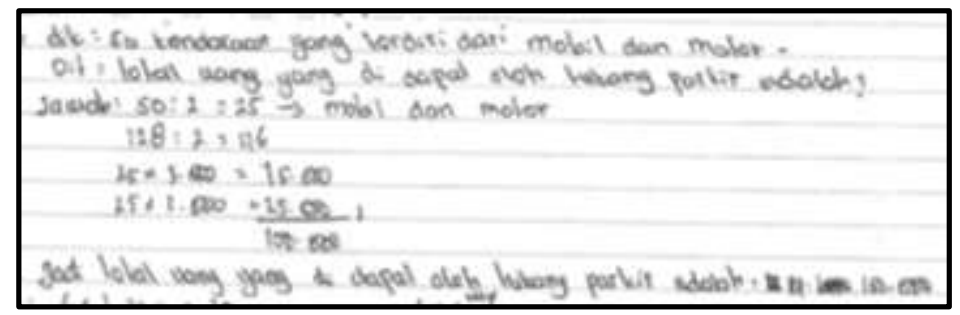

Gambar 4. Jawaban Subjek $\mathrm{SE}_{2}$ Soal No. 1

Berdasarkan Gambar 4 diatas, terlihat bahwa subjek $\mathrm{SE}_{2}$ melakukan tahap memahami masalah meskipun kurang lengkap, melakukan tahap membuat rencana tetapi salah menuliskan rencana, menuliskan langkah-langkah penyelesaian masalah pada soal meskipun masih terdapat kesalahan. Serta menuliskan kesimpulan jawaban meskipun kurang tepat.

\subsection{Tipe Kepribadian Ambivert}

Berdasarkan Tabel 3 diatas, terlihat bahwa total rata-rata skor kemampuan pemecahan masalah matematika siswa tipe kepribadian ambivert adalah sebesar 22,65. Hal ini menunjukkan bahwa kemampuan pemecahan masalah matematika yang dimiliki oleh siswa tipe kepribadian ambivert masih sangat kurang. Berikut ditampilkan hasil tes salah satu siswa dengan tipe kepribadian ambivert. 


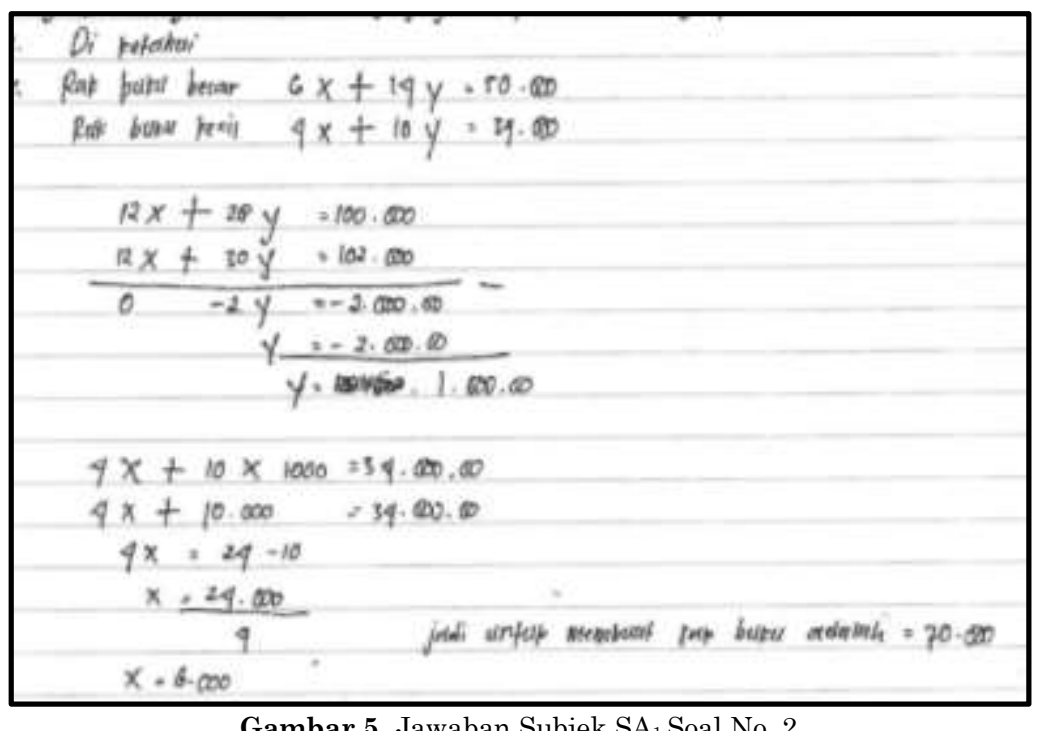

Berdasarkan Gambar 5 diatas, terlihat bahwa subjek $\mathrm{SA}_{1}$ tidak menuliskan diketahui dan ditanyakan pada soal. Dapat melakukan tahap membuat rencana dengan langsung menuliskan simbol matematikanya. menuliskan langkah penyelesaian sesuai rencana yang dibuat, serta menuliskan kesimpulan jawaban dari soal yang diberikan.

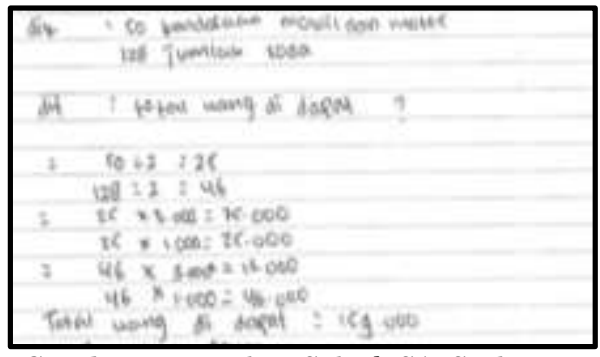

Gambar 6. Jawaban Subjek $\mathrm{SA}_{2}$ Soal No. 1

Berdasarkan Gambar 6 diatas, terlihat bahwa subjek $\mathrm{SA}_{2}$ menuliskan yang diketahui dan ditanyakan hanya pada soal no. 1. Dapat membuat rencana meskipun masih terdapat kesalahan. Melakukan tahap melaksanakan rencana meskipun masih terdapat kesalahan langkah. Menuliskan kesimpulan dari semua soal dan melakukan pemeriksaan kembali sebelum mengumpulkan.

\subsection{Pembahasan}

\subsubsection{Kemampuan Pemecahan Masalah Siswa Tipe kepribadian Introvert}

Berdasarkan hasil penelitian, simpulkan bahwa pada tahap memahami masalah siswa introvert belum mampu melakukannya, siswa masih salah dalam menuliskan informasi yang diketahui dan ditanyakan dari soal bahkan pada beberapa soal siswa tidak menuliskan informasi-informasi tersebut. Tetapi pada saat wawancara siswa tipe kepribadian introvert mampu menyebutkan apa yang diketahui dan ditanyakan dengan membaca ulang soal. Siswa introvert tidak menuliskan simbol yang akan digunakan tetapi menuliskannya ke bentuk matematika dengan benar. Sedangkan berdasarkan 
hasil wawancara siswa introvert kurang mampu menjelesakan rencana penyelesaian menggunakan bahasanya sendiri. Hal ini sejalan dengan hasil penelitian dari Jazuli \& Lathifah (2018) yang menyatakan bahwa siswa introvert mampu melakukan tahap membuat rencana tetapi masih kurang dalam menjelesakan rencana yang telah disusun menggunakan bahasa sendiri. Pada tahap melaksanakan rencana siswa introvert sudah mampu menuliskan penyelesaian masalah berdasarkan rencana yang dibuat dari beberapa soal dengan benar dan sistematis, meskipun pada beberapa soal lainnya masih terdapat kesalahan penyelesaian. Kemudian pada tahap melihat kembali siswa introvert sudah mampu melakukannya dengan menuliskan pemeriksaan kembali jawaban atau menuliskan kesimpulan penyelesaian masalah dari soal yang diberikan dan berdasarkan hasil wawancara siswa introvert sudah melakukan pemeriksaan kembali jawaban sebelum mengumpulkannya. Pada saat mengerjakan siswa introvert lebih tenang dalam menyelesaikan soal dan tidak tergesa-gesa, serta berusaha menyelesaikan soal berdasarkan kemampuan sendiri. Hal ini sejalan dengan pendapat dari Sunaryo (2004) yang menyatakan bahwa pada saat mengalami masalah seorang dengan tipe kepribadian introvert akan tenggelam dalam pikirannya sendiri dan merasa mampu menghadapi seorang diri. Sedangkan menurut Burtverde \& Mihaila (2011) introvert yang takut untuk gagal membuat mereka lebih berhati-hati, sedikit melakukan kesalahan, tetapi memerlukan waktu yang cukup banyak untuk berpikir.

\subsubsection{Kemampuan Pemecahan Masalah Siswa Tipe kepribadian Extrovert}

Berdasarkan hasil penelitian, disimpulkan bahwa pada tahap memahami masalah, siswa tipe kepribadian extrovert belum sepenuhnya mampu menuliskan informasi-informasi yang diberikan pada soal yaitu menuliskan apa yang diketahui dan ditanyakan soal. Namun berdasarkan hasil wawancara siswa dapat menyebutkan apa yang diketahui dan ditanyakan dari soal dengan benar. Hal tersebut sejalan dengan hasil penelitian dari Juliansa, Kartinah, \& Purwosetiyono (2019) yang menyatakan bahwa siswa extrovert belum mampu memahami masalah dengan baik, siswa tidak menuliskan yang diketahui dan ditanyakan dari soal dan kurang mampu menyebutkan menggunakan bahasa sendiri. Pada beberapa soal siswa extrovert sudah mampu membuat rencana penyelesian meskipun kurang lengkap dan sistematis, sedangkan pada beberapa soal lainnya siswa extrovert kurang mampu menuliskan rencana penyelesaian. Sejalan dengan penelitian dari Ain, Baidowi \& Hapipi (2020) yang menyampaikan bahwa siswa yang memiliki kemampuan pemecahan masalah kurang baik mampu melakukan tahap membuat rencana penyelesaian hanya pada beberapa soal saja dan tidak mampu membuat rencana pada beberapa soal lainnya karena beranggapan soal tersebut sulit. Melakukan tahap melaksanakan rencana dengan menuliskan penyelesaian masalah dari soal sesuai rencana yang dibuat walaupun pada beberapa soal terdapat kesalahan dalam perhitungan sehingga mendapatkan hasil yang salah. Pada tahap melihat kembali dapat menuliskan pemeriksaan kembali jawaban tetapi kurang lengkap dan sistematis. Siswa menyadari beberapa kesalahan yang dibuat saat melakukan pemeriksaan kembali, tetapi siswa tidak berusaha memperbaiki kesalahan tersebut. Hal ini mencerminkan 
sifat seorang extrovert yaitu tergesa-gesa dalam melakukan pekerjaan, serta tidak terlalu memikirkan kegagalan yang didapatkan. Seperti yang diungkapkan oleh Sunaryo (2004) seorang extrovert cenderung bersifat spontan dalam mengungkapkan emosi, tidak terlalu memikirkan kegagalan yang dihadapi, serta tidak banyak menganalisis dan mengkritik diri atas kegagalannya.

\subsubsection{Kemampuan Pemecahan Masalah Siswa Tipe kepribadian Ambivert}

Berdasarkan hasil penelitian, disimpulkan bahwa pada tahap awal yaitu tahap memahami masalah siswa ambivert hanya mampu menuliskan informasi yang diketahui dan ditanyakan pada beberapa soal saja tetapi kurang lengkap dan sistematis, sedangkan pada soal lainnya tidak menuliskan informasi tersebut. Tetapi pada saat wawancara siswa ambivert mampu menyebutkan apa yang diketahui dan ditanyakan dari soal dengan benar. Menuliskan perencanaan dengan langsung mengubahnya ke bentuk matematika serta pada saat membuat rencana siswa ambivert terlihat kesulitan menentukan rencana seperti apa yang akan digunakan, bahkan beberapa kali siswa terlihat menanyakan perencanaan penyelesaian soal yang tepat kepada temannya. Selanjutnya pada tahap melaksanakan rencana, siswa ambivert mampu menuliskan penyelesaian masalah dari soal sesuai rencana yang dibuat meskipun masih terdapat kesalahan langkah. Tahap terakhir yaitu tahap melihat kembali, siswa ambivert mampu melakukan tahap melihat kembali dengan menuliskan kesimpulan jawaban dari semua soal yang diberikan meskipun masih terdapat kesalahan hasil akhir yang didapatkan serta telah melakukan pemeriksaan kembali jawaban sebelum mengumpulkannya dan meyakini bahwa langkah-langkah yang digunakan serta jawaban yang diperoleh sudah benar. Uniknya, kedua subjek yang digunakan memiliki kecendrungan yang berbeda, hal ini berdasarkan sifat seorang ambivert yang merupakan gabungan dari tipe kerpibadian introvert dan extrovert sehingga sulit mengkategorikan pada salah satunya, sifat yang dapat berubah-ubah tergantung suasana hati, situasi yang sedang dihadapi, dan lawan bicara (Manno, 2020).

\section{SIMPULAN}

Berdasarkan hasil penelitian, pembahasan diatas dan mengacu pada tujuan penelitian, maka diperoleh kesimpulan bahwa kemampuan pemecahan masalah matematika ditinjau dari tipe kepribadian siswa kelaas VIII MTs Al-Ma'arif NU Qamarul Huda Narmada Tahun Pelajaran 2020/2021 adalah adalah siswa tipe kerpibadian introvert dan extrovert belum mampu melakukan tahap memahami masalah, melakukan tahap membuat rencana dengan langsung menuliskannya ke bentuk matematika, menuliskan penyelesaian masalah dengan sistematis tetapi masih ada beberapa kesalahan, 
menuliskan kesimpulan jawaban meskipun kurang tepat. Sedangkan siswa tipe kepribadian ambivert mampu melakukan tahap memahami masalah meskipun kurang lengkap, menuliskan rencana penyelesaian dari soal dengan langsung menuliskannya ke bentuk matematika, menuliskan penyelesaian soal sesuai rencana meskipun terdapat beberapa kesalahan langkah, melakukan pemeriksaan kembali dan menuliskan kesimpulan meskipun terdapat kesalahan hasil.

\section{.5. REKOMENDASI}

Rekomendasi untuk penelitian selanjutnya, dapat mengembangkan penelitian serupa dengan memperhatikan faktor-faktor lain yang mungkin mempengaruhi tipe kepribadaian seperti lingkungannya serta dapat mengembangkan soal tes kemampuan pemecahana masalah matematika agar lebih bervariasi.

\section{REFERENSI}

Ain, H., Baidowi \& Hapipi (2020). Kemampuan Siswa Dalam Pemecahan Masalah Geometri Berdasarkan Tingkat Berpikir Van Hiele. Jurnal Pijar MIPA. 15 (3), 273 - 279.

Aryanto, E. W., Suharto, Setiawan, T. B., Hobri, \& Oktavianingtyas, E., (2018). Profil Kemampuan Siswa Dalam Memecahkan Masalah Matematika Ditinjau Dari Tipe Kepribadian Menurut David Keirsey. Jurnal Kadikma. 9 (2), 185-193.

Burtaverde, V., \& Mihaila, T. (2011). Significant Differences Between Introvert And Extrovert People's Simple Reaction Time In Conflict Situations. Romanian Journal Of Experimental Applied Psychology. 2 (3), 18-24.

Dari, D.A.W., \& Budiarto M.T. (2016). Profil Pemecahan Masalah Matematika Siswa SMP Kelas VIII Ditinjau Dari Tingkat Kecerdasan Emosional Dan Kemampuan Matematika.Jurnal Ilmiah Pendidikan Matematika. 1 (5), 14-20.

Hadi, S. \& Radiyatul. (2014). Metode Pemecahan Masalah Menurut Polya Untuk Mengembangkan Kemampuan Siswa Dalam Pemecahan Masalah Matematis Di Sekolah Menengah Pertama. EDU-MAT Jurnal Pendidikan Matematika. 2 (1), 53 - 61.

Hidayat, W., \& Sariningsih R. (2018). Kemampuan Pemecahan Masalah Matematis Dan Adversity Quotient Siswa SMP Melalui Pembelajaran Open Ended. Jurnal Nasional Pendidikan Matematika. 2 (1), 109-118.

Jazuli, A., \& Lathifah, M. (2018). Deskripsi Kemampuan Pemecahan Masalah Matematis Pada Soal Cerita Berdasrkan Tipe Kepribadian Ekstrovert-Introvert Siswa SMP Negeri 6 Rembang. Journal Of Mathematics Education. 1 (4), 23-32.

Juliansa, M.F., Kartinah, \& Purwosetiyono, D. FX. (2019). Kemampuan Pemecahan Masalah Matematika Siswa Kelas X Dalam Mengerjakan Soal Cerita Pada Siswa Tipe Kepribadian Ekstrovert Dan Introvert. Imajiner: Jurnal Matemtaaika dan Pendidikan Matematika. 1 (5), 133-137.

Manno, D. (2020). Building Your Future Pembentukan Watak Dan Tata Nilai Untuk Menjadi Pribadi Unggul. Yogyakarta: PBMR ANDI. 
Subadi, T. (2006). Metode Penelitian Kualitatif. Surakarta: Muhammadiyah University Press.

Turmuzi, M. (2019). Evaluasi Proses dan Hasil Belajar Matematika. Mataram: Universitas Mataram.

Turmuzi, M. \& Hayati, L. (2012). Telaah Kurikulum Matematika. Mataram: Arga Puji Press.

Pimta, S., Tayruakham S., \& Nuangchalerm P. (2009). Factors Influencing Mathematic ProblemSolving Ability Of Sixh Grade Students. Journal Of Social Sciences. 5 (4), 381-385.

Rahmawati, P. (2018). Mengenal Pemecahan Masalah Matematika Siswa Perbatasan. Yogyakarta: Deepublish.

Sunaryo, (2004). Psikologi Untuk Keperawatan. Jakarta: EGC.

Susanto, H.A. (2019). Pemahaman Pemecahan Masalah Berdasarkan Gaya Kognitif. Yogyakarta: Deepublish.

Wahyudi, \& Anugraheni, I. (2017). Strategi Pemecahan Masalah Matematika. Salatiga: Satya Wacana University Press.

Widayanti, L. (2016). Deskripsi Level Kemampuan Siswa SMP Dengan Tipe Kepribadian Cenderung Introvert Dalam Menyelesaikan Masalah Matematika. Jurnal Edukasi. 2 (1), 83-94. 